\title{
RESULTS OF A DOMICILIARY REHABILITATION PROGRAM FOR CHRONIC LOW BACK PAIN PATIENTS
}

\author{
RESULTADOS DE UM PROGRAMA DE REABILITAÇÃO DOMICILIAR PARA PORTADORES \\ DE LOMBALGIA CROONICA
}

\author{
RESULTADOS DE UN PROGRAMA DE REHABILITACIÓN DOMICILIARIA PARA PACIENTES \\ CON LUMBALGIA CRÓNICA
}

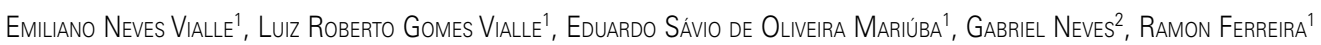

\begin{abstract}
Objective: To evaluate the results of a home rehabilitation program for patients with chronic low back pain through the evaluation of abdominal muscle strength, lumbar mobility, daily activities and improved levels of pain. A secondary objective was to evaluate the adherence of the participants to this program.Methods: We evaluated 99 patients divided into case group (69 patients with chronic low back pain without indication for surgical treatment) and control group (30 patients without low back pain), the following parameters being measured: 1) lumbar mobility, 2) strength of the abdominal muscles, 3) pain by visual analog scale (VAS), 4) limitation in daily activities (Oswestry scale). Patients received individualized guidance on home exercises to be performed during two months. For comparison of groups "control" and "case" the nonparametric Mann Whitney test was applied. For comparison of the times "before" and "after" in the group of patients who returned, the nonparametric Wilcoxon test was applied. Results: Of the 69 patients who agreed to participate, 30 completed the targeted exercises within two months and returned for the final evaluation. At baseline, there was a significant difference $(p<0.05)$ between the case and control groups for lumbar mobility and abdominal strength. In the case group there was significant improvement in all aspects evaluated at the end of the exercise program. Conclusion: The home rehabilitation program was effective as a treatment option for low back pain. Treatment adherence was low, this being the main limiting factor.
\end{abstract}

Keywords: Low back pain; Physical fitness; Rehabilitation; Residential treatment; Treatment outcome.

\section{RESUMO}

Objetivo: Avaliar a influência de um programa de reabilitação domiciliar para portadores de dor lombar crônica por meio da avaliação de força muscular abdominal, mobilidade lombar, atividades diárias e melhora dos níveis de dor. Um objetivo secundário foi avaliar a adesão dos participantes a este programa. Métodos: Foram avaliados 99 pacientes divididos em grupo caso (69 pacientes com lombalgia crônica, sem indicação de tratamento cirúrgico) e grupo controle (30 pacientes sem lombalgia), medindo-se os seguintes parâmetros: 1) mobilidade lombar, 2) resistência da musculatura abdominal, 3) dor pela escala visual analógica de dor (EVA), 4) limitação nas atividades diárias (escala de Oswestry). Os pacientes receberam orientação individualizada sobre os exercícios domiciliares, a serem realizados por dois meses. Para a comparação dos grupos "controle" e "caso" foi aplicado o teste não paramétrico de Mann Whitney. Para comparação dos tempos "antes" e "depois" no grupo de pacientes que retornaram, foi aplicado o teste não paramétrico de Wilcoxon. Resultados: Dos 69 pacientes que aceitaram participar, 30 concluíram os exercícios orientados no período de dois meses e retornaram para avaliação final. Na avaliação inicial, observou-se diferença significativa ( $p<0,05)$ entre os grupos caso e controle para mobilidade lombar e resistência abdominal. No grupo caso, houve melhora significativa em todos os quesitos avaliados ao término do programa de exercícios. Conclusão: O programa de exercícios domiciliar foi eficaz como opção terapêutica para dor lombar. A adesão ao tratamento foi baixa, sendo este seu principal fator limitante.

Descritores: Dor lombar; Aptidão física; Reabilitação; Tratamento domiciliar; Resultado de tratamento.

\section{RESUMEN}

Objetivo: Evaluar la influencia de un programa de rehabilitación domiciliaria para pacientes con lumbalgia através de la evaluación de la fuerza muscular abdominal, la movilidad lumbar, las actividades diarias y la mejoría de los niveles del dolor. Un objetivo secundario fue evaluar la adherencia de los participantes en este programa. Métodos: Se evaluaron 99 pacientes divididos en grupo caso (69 pacientes con lumbalgia crónica) y grupo control (30 pacientes sin lumbalgia), mediante la medición de los siguientes parámetros: 1) movilidad lumbar, 2) fuerza de la musculatura abdominal, 3) dolor mediante la escala visual análoga de dolor (EVA), 4) limitación en las actividades diarias (escala de Oswestry). Los pacientes recibieron orientación individualizada sobre ejercicios domiciliarios, para llevarse a cabo por dos meses. Para la comparación de los grupos "control" y "caso" se aplicó la prueba no paramétrica de Mann Whitney. Para la comparación de los tiempos "antes" y "después" en el grupo de pacientes que regresaron, se aplicó la prueba no paramétrica de Wilcoxon. Resultados: De los 69 pacientes que aceptaron participar, 30 completaron los ejercicios específicos en el plazo de dos meses y regresaron para la evaluación final. En la evaluación del inicio del estudio, no hubo diferencias significativas $(p<0,05)$ entre los grupos caso y control para la movilidad lumbar y la fuerza abdominal. En el grupo caso se observó una mejoría significativa en todas las variables evaluadas al final del programa de ejercicios. Conclusión: El programa de ejercicios domiciliarios fue eficaz como una opción terapéutica para el tratamiento del dolor lumbar. La adherencia al tratamiento fue baja, siendo este su principal factor limitante.

Descriptores: Dolor de la región lumbar; Aptitud física; Rehabilitación; Tratamiento domiciliario; Resultado del tratamiento.

1. Spine Surgery Group, Hospital Universitário Cajuru, Pontifícia Universidade Católica do Paraná, Curitiba, Paraná, Brazil.

2. Clinica da Coluna Vertebral, Curitiba, Paraná, Brazil.

Study conducted at the Spine Surgery Outpatient Clinic of the Hospital Universitário Cajuru (PUC), PR, Brazil.

Correspondence: Rua Brigadeiro Franco, 979. 80430-210. Curitiba, PR, Brasil. evialle@ hotmail.com 


\section{INTRODUCTION}

Low back pain is considered a public health problem worldwide, and one of the main causes of visits to the doctor and time off work. Low back pain is more common after the fourth decade of life, in females, and where there is a positive family history. Although it may seem obvious to many, there is little data demonstrating the link between low back pain and anthropometric parameters. ${ }^{1}$

As a conservative therapeutic option for low back pain, greater efficiency of muscle resistance exercises, compared to aerobic exercises, has already been demonstrated ${ }^{2}$ with the best results being obtained with more frequent exercises. ${ }^{3}$ The superiority of physical exercises over electrotherapy has also been reported ${ }^{4}$ as has the fact that better results are achieved in males. ${ }^{5}$

Richmond ${ }^{6}$ reported the multifactorial etiology of low back pain, and hence, the difficulty of treating it. The author reaffirmed the relationship between low back pain, musculature, and flexibility, demonstrating the large and complex interarticular and postural relationship in the source of low back pain.

Critchley and Coults, ${ }^{7}$ using ultrasound, evaluated the transverse abdominal muscle of patients at rest, concluding that dysfunction can be identified in patients with chronic low back pain, their rehabilitation being part of the treatment.

Kuukkanen and Malkia ${ }^{8}$ found benefits through stretching only for patients with severe limitations in the activities of daily living, and that these benefits were lost in patients who did not continue to perform the exercises.

Grewal et al. ${ }^{9}$ reported several non-surgical treatment options for low back pain, with different levels of evidence for each method. The scientific evidence is stronger in studies that use patient education and strengthening exercises for the abdominal, lumbar and pelvic muscles.

Fairbanks et al..$^{10}$ demonstrated that after 24 months of follow-up, there was no difference between conservative and surgical treatment of low back pain in situations where surgery is not essential (fracture, tumor, inflammatory diseases).

Brox et al..$^{11}$ demonstrated after two years of follow-up, and Froholdt et al. ${ }^{12}$ after nine years, that treatment with an intensive rehabilitation protocol showed comparable results to surgical treatment in patients with low back pain.

The objective of this work was to evaluate the influence of a rehabilitation program performed at home, for patients with chronic lumbar pain through: $A$ ) assessment of abdominal muscle strength; B) lumbar mobility; (C) activities of daily living; and D) improvement in the levels of pain. The secondary objective was to assess the adherence of the participants to this program.

\section{MATERIAL AND METHODS}

Patients of the General Orthopedics and Spine Surgery Outpatient Clinic were invited to take part in the study. The inclusion criteria were: being of the legal age; being able to read, understand and sign the informed consent form; having no physical limitations that would prevent the participant from performing the exercises; having symptoms of low back pain but without indication for surgery as in cases of stenosis of the spinal canal, disc herniation with radicular pain, spondylolisthesis or degenerative scoliosis. This study was approved by the Ethics Committee of the Institution, and all the subjects signed an Informed Consent Form for participation in this study.

The group consisted of 99 patients (Table 1); 69 patients with chronic lumbar pain and 30 without a history of low back pain who attended the outpatient clinic for some other reason (completion of treatment for fractures, dislocations and limb injuries).

The patient's personal data were noted (age, sex, weight, height, body mass index (BMI), level of education, profession, and practice of recreational and sports activities).

The flexibility of the patient's spine was determined by measuring the distance between the ground and the patient's fingers. The patient remained in the orthostatic position, while performing maximum active flexion of the spine, without bending the knees or hips. (Figure 1)
Abdominal muscle strength was measured by counting the number of sit-ups performed in one minute. The patient, in the supine position with the knees flexed at $90^{\circ}$ and the hands supported under the head, performed sit-ups by flexing the abdominal muscles, raising the shoulder blades off the ground. (Figure 2)

The patients with low back pain who agreed to take part in the study were then given a list of stretching and strength-building exercises, and detailed instructions, with each exercise being explained and then performed by the patient during the visit. (Figure 3)

A return visit was scheduled for all the patients with low back pain, and those who had completed the two months of guided exercises filled out a weekly report (citing possible limitations of the method). On the return visit, the hand-ground distance, the number of sit-ups per minute, and the Oswestry ${ }^{13}$ and Visual Analogue Scale (VAS) were measured again. ${ }^{14}$

Initially, the statistically descriptive measurements were calculated, with the aim of summarizing the data set, through the calculation of: means, standard deviations, maximum and minimum values. The normality of the study variables was determined through the Lilliefors test ${ }^{15}$ and the variables of interest did not present normality. The Mann-Whitney non-parametric test ${ }^{16}$ was used to compare the "control" and "case" groups; the whole case group that began the study and the case group that completed the study; the baseline and final characteristics of the patients in the case group who completed the study; and the patients in the case group who completed the treatment and the control group.

Table 1. Characteristics of the study patients.

\begin{tabular}{c|c|c}
\hline & Case group (n=69) & Control group (n=30) \\
\hline Female & 45 & 15 \\
\hline Male & 14 & 15 \\
\hline $\begin{array}{c}\text { Practiced regular } \\
\text { physical activity }\end{array}$ & 20 & 14 \\
\hline Manual laborer & 32 & 6 \\
\hline $\begin{array}{c}\text { Complete high school } \\
\text { education }\end{array}$ & 18 & 20 \\
\hline
\end{tabular}

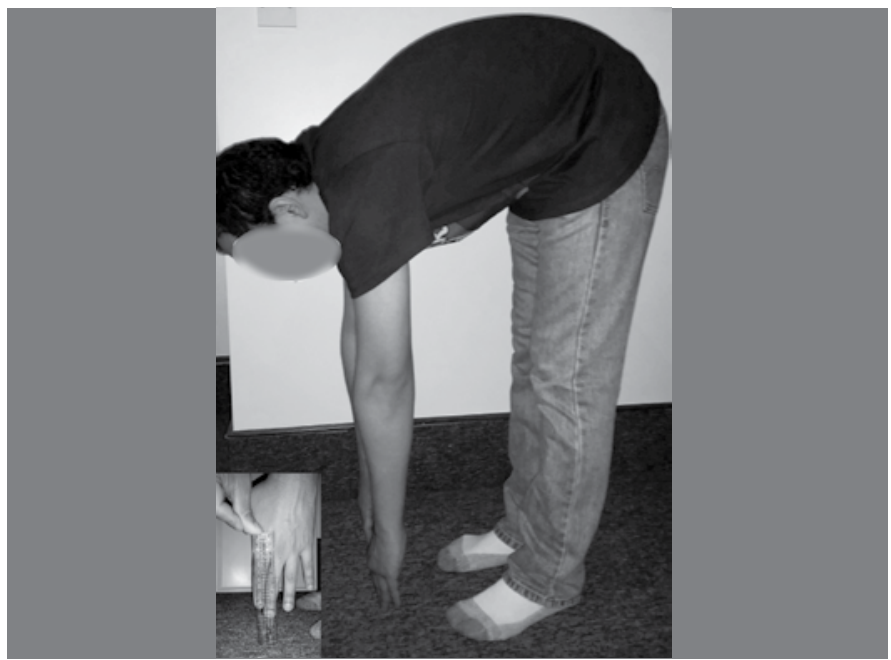

Figure 1. Hand-ground distance measurement.

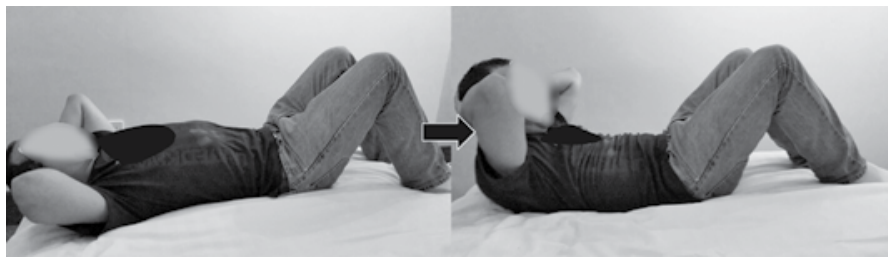

Figure 2. Form of guidance to perform the sit-ups 


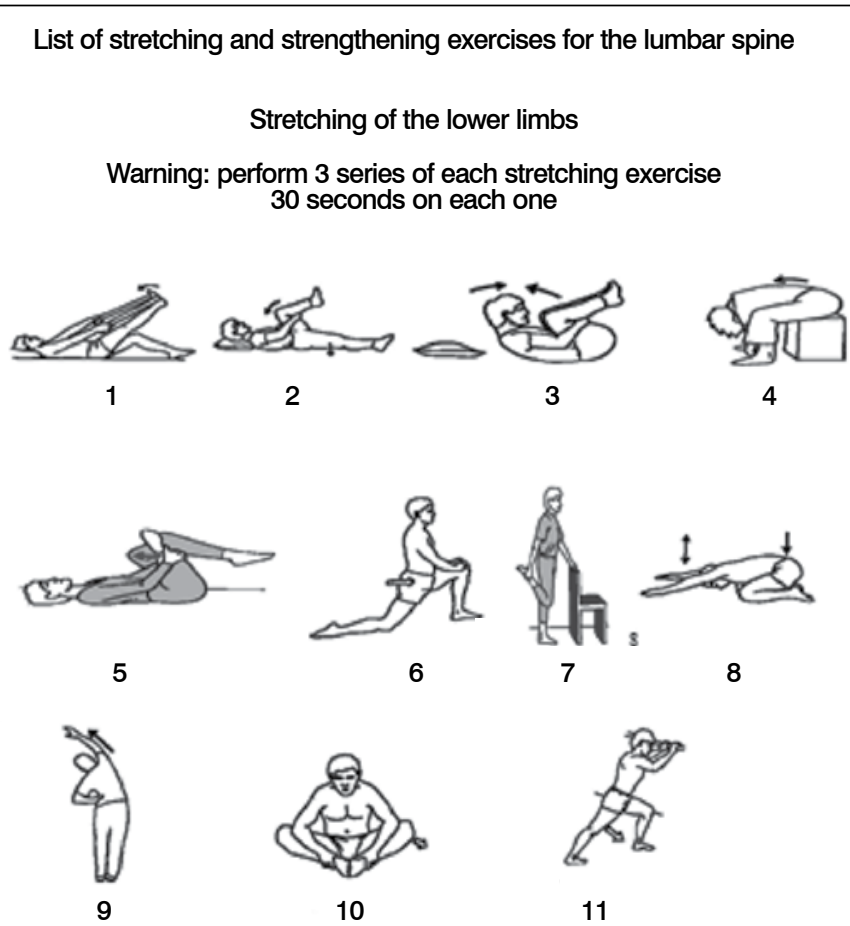

Strengthening exercises for the lower limbs

Note: perform 3 series of 10 repetitions for each exercise

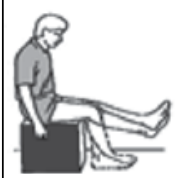

1

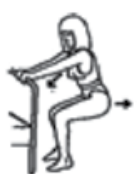

6

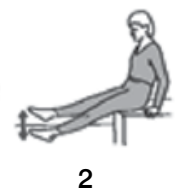

2

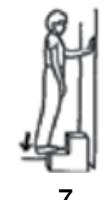

7

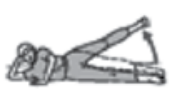

3

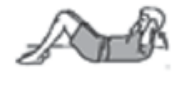

8

4
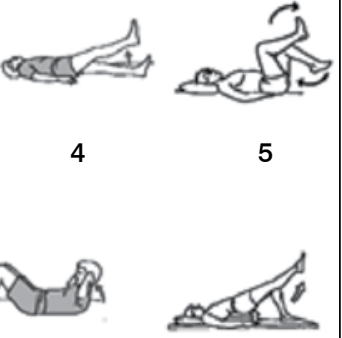

9
Figure 3. List of guided exercises given to the patients.

\section{RESULTS}

Most of the patients in both the case and control groups did not perform regular physical activity. In the group with low back pain, this proportion was higher (approximately 3:1).

The group with low back pain was on average 16.6 years older and had a BMI $3.4 \mathrm{~kg} / \mathrm{m}^{2}$ higher than the control group. (Table 2)

The patients with low back pain had decreased abdominal resistance and less flexibility of the posterior muscular chain (hand-ground distance test) compared with those of the control group. (Figure 4) The patients with low back pain performed an average of 19.61 sit-ups per minute, and had a hand-ground distance of 9.48 $\mathrm{cm}$ more than the group without low back pain, with both measurements showing statistically significant difference.

In the reassessment after two months, 39 patients had not completed the study, either because they did not return, or because they did not carry out the complete program of exercises. The 69 patients initially included in the study had an average age of 49.87 years and had had the disease for an average of 8.6 years. The 30 patients who completed the program of exercises had an average age of 47.52 years and had had the disease for an average of 7.26 years.
(Table 3) There was no statistically significant difference between the total group of patients initially included in the study and the group of patients who returned.

In the return evaluation of the patients with low back pain, there was statistically significant change in the following variables: number of sit-ups per minute $(p=0.01000)$ with an average increase of 7.83 sit-ups per minute, hand-ground distance $(p=0.000215)$, with an average reduction of $10.4 \mathrm{~cm}$ of distance, VAS ( $p=0.000002)$ with an average reduction of 3.36 , and Oswestry $(p=0.000006)$, with an average reduction of 8.1 . (Figure 5)

In the comparison between the control group and the group of patients who returned after completing the rehabilitation, despite an increase in the number of sit-ups per minute, the difference remained significant in this criterion ( $p=0.0073$ ). Comparing the groups, there was no significant difference in relation to the hand-ground distance, with the case group showing the best results. (Table 4)

Within the treated group, there was a difference between sexes only in the improvement of the hand-ground distance characteristic, with females having more favorable results than males.

Table 2. Age, weight, height and BMl of the patients evaluated.

\begin{tabular}{c|c|c|c}
\hline & Case group $(\mathbf{n}=69)$ & Control group $(\mathbf{n = 3 0})$ & $\mathbf{p}$ \\
\hline Age & 49.9 years $( \pm 11.8)$ & 33.3 years $( \pm 11.1)$ & 0.0001 \\
\hline Weight & $71.9 \mathrm{~kg}( \pm 10.6)$ & $67.4 \mathrm{~kg}( \pm 9.7)$ & 0.052 \\
\hline Height & $1.62 \mathrm{~m}( \pm 0.09)$ & $1.67 \mathrm{~m}( \pm 0.06)$ & 0.005 \\
\hline BMI & $27.6 \mathrm{~kg} / \mathrm{m}^{2}( \pm 4.5)$ & $24.2 \mathrm{~kg} / \mathrm{m}^{2}( \pm 2.8)$ & 0.00025 \\
\hline
\end{tabular}

$(\mathrm{BMI}=$ Body Mass Index, $\mathrm{p}=$ statistical significance)

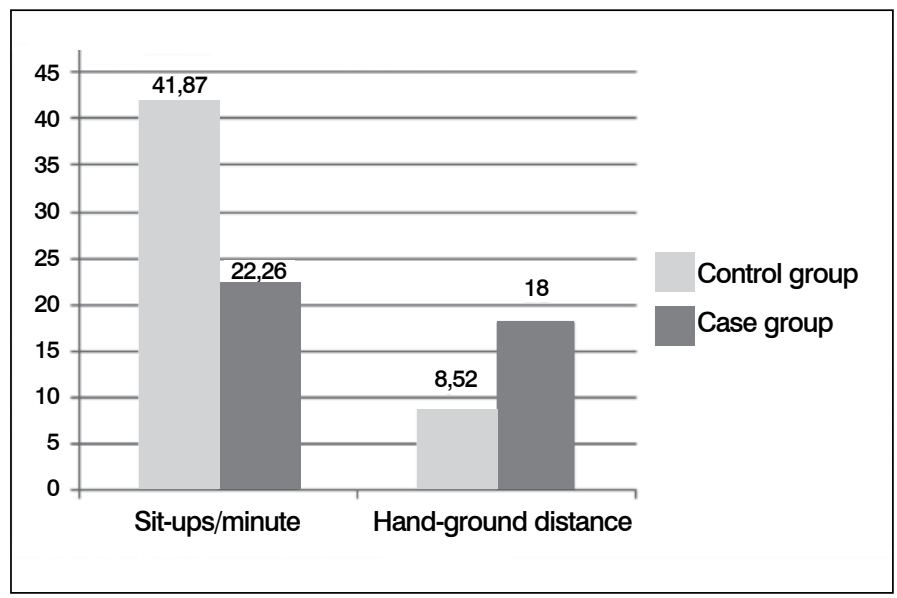

Figure 4. Evaluation of the number of sit-ups per minute and hand-ground distance of the patients initially evaluated.

Table 3. Evaluation of the patients who returned after completing the guided exercises.

\begin{tabular}{c|c|c|c}
\hline & Initial group $(\mathbf{n = 6 9 )}$ & Final group $(\mathbf{n = 3 0})$ & $\mathbf{p}$ \\
\hline Age & 49.9 years $( \pm 11.8)$ & 47.52 years $( \pm 12.25)$ & 0.35 \\
\hline $\begin{array}{c}\text { Time with the } \\
\text { disease }\end{array}$ & 8.6 years & 7.26 years & 0.33 \\
\hline Weight & $71.9 \mathrm{~kg}( \pm 10.6)$ & $73 \mathrm{~kg}( \pm 13.08)$ & 0.61 \\
\hline Height & $1.62 \mathrm{~m}( \pm 0.09)$ & $1.61( \pm 0.07)$ & 0.52 \\
\hline BMI & $27.6 \mathrm{~kg} / \mathrm{m}^{2}( \pm 4.5)$ & $28.41 \mathrm{~kg} / \mathrm{m}^{2}( \pm 5.4)$ & 0.48 \\
\hline
\end{tabular}

(BMI = Body Mass Index, $\mathrm{p}=$ statistical significance). 


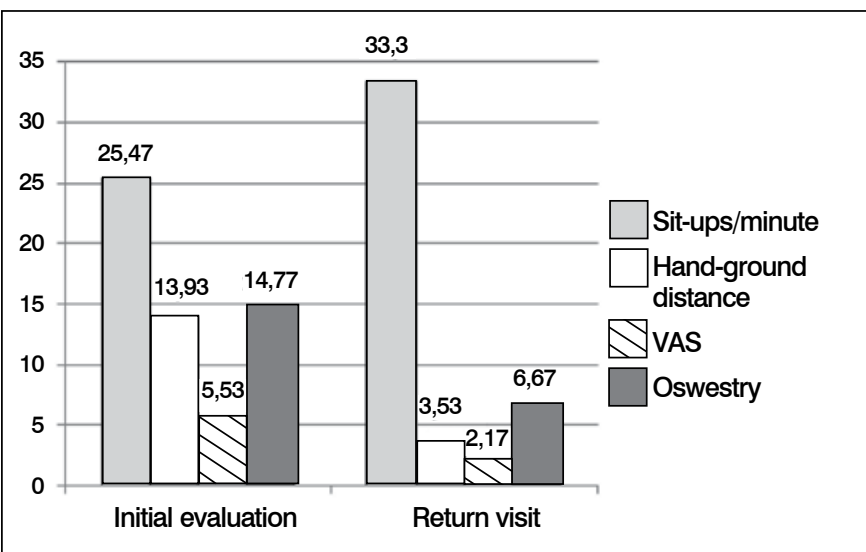

Figure 5. Number of sit-ups per minute, hand-ground distance, and VAS (Visual Analogue Scale) and Oswestry scores found in the baseline visit and after the return of the patients who completed the study.

Table 4. Comparison between number of sit-ups per minute and hand-ground distance between patients of the control group and patients of the case group who completed the proposed treatment ( $p=$ statistical significance).

\begin{tabular}{c|c|c|c}
\hline & Case group $(\mathbf{n}=69)$ & Control group $(\mathbf{n}=\mathbf{3 0})$ & $\mathbf{p}$ \\
\hline Sit-ups & $33.33( \pm 13.48)$ & $41.87( \pm 13.9)$ & 0.0073 \\
\hline $\begin{array}{c}\text { Hand-ground } \\
\text { distance }\end{array}$ & $3.53( \pm 7.94)$ & $8.52 \mathrm{~cm}( \pm 8.58)$ & 0.06763 \\
\hline
\end{tabular}

\section{DISCUSSION}

One of the great difficulties of rehabilitation, in our country, is to reach the standards of physical activity necessary to improve the underlying condition. Several studies have demonstrated the effectiveness of physical activity and rehabilitation in the treatment of low back pain. ${ }^{16-18}$ However, the complexity and intensity of these rehabilitation programs are difficult to reproduce. Many of the patients included in this study reported that despite having participated in physiotherapy sessions for the same problem previously, they had not performed the exercises prescribed in the protocol.

The protocol used in this study was prepared as a course con- clusion thesis ${ }^{19}$ using proven methods, with sufficient scientific evidence and the authors' personal experience in the conservative treatment of low back pain.

As in Poiraudeau and Revel, ${ }^{20}$ in this study, the patients also performed exercises to strengthen the paravertebral muscles, showing short- and medium-term improvement in low back pain.

Vasseljen and Fladmark ${ }^{21}$ showed that patients who performed exercises for abdominal strengthening for eight weeks showed an improvement in low back pain, just as in this study.

Handa et al. ${ }^{22}$ found, in all 30 patients aged 40 years or over, and who had not carried out previous programs of exercise, like the majority of patients in this study, an improvement in low back pain after strengthening exercises for the trunk.

The gain in flexibility of column found in the patients in this study was also observed in a study by Shum et al. ${ }^{23}$ who demonstrated that after the gain in range of motion in flexion-extension of the spine, there was improvement in low back pain and also a longer time to recurrence of the pain

As was evidenced in this study, several studies have also demonstrated an association between loss of mobility of the spine and low back pain. ${ }^{24-26}$ In this study, the patients who showed improvement in this characteristic also showed improvement in the pain symptoms.

Besides lumbar flexibility, shortening of the quadriceps and hamstrings, ${ }^{17}$ reduced strength of the extensor muscles of the spine, and hip flexors and adductors ${ }^{18}$ are also related to low back pain. The guided exercises in this study also promoted improvements in these muscle groups, leading to an improvement in low back pain.

\section{CONCLUSION}

The rehabilitation program was effective in improving the abdominal strength, the stretching of the posterior muscle chain, the quality of activities of daily living and in reducing the levels of pain.

Adherence to the exercise program was low, this being the main limiting factor of the study.

All authors declare no potential conflict of interest concerning this article.

\section{REFERENCES}

1. Celan $D$, Turk $Z$. The impact of anthropometric parameters on the incidence of low back pain. Coll Antropol. 2005:29(1):101-5.

2. Kell RT, Asmundson GJ. A comparison of two forms of periodized exercise rehabilitation programs in the management of chronic nonspecific low-back pain. J Strength Cond Res. 2009;23(2):513-23.

3. Kell RT, Risi AD, Barden JM. The response of persons with chronic nonspecific low back pain to three different volumes of periodized musculoskeletal rehabilitation. J Strength Cond Res. 2011;25(4):1052-64

4. Kumar S, Sharma VP, Negi, MPS. Efficacy of dynamic muscular stabilization techniques (DMST) over conventional techniques in rehabilitation of chronic low back pain. J Strength Cond Res. 2009;23(9):2651-9

5. Kumar S, Sharma VP, Shukla R, Dev R. Comparative efficacy of two multimodal treatments on male and female sub-groups with low back pain (part II). J Back Musculoskelet Rehabil. 2010;23(1):1-9.

6. Richmond J. Multi-factorial causative model for back pain management; relating causative factors and mechanisms to injury presentations and designing time- and cost effective treatment thereof. Med Hypotheses. 2012;79(2):232-40.

7. Critchley DJ, Coutts FJ Abdominal muscle function in chronic low back pain patients: measurement with real-time ultrasound scanning. Physiotherapy. 2002:88(6): 322-32.

8. Kuukkanen T, Mälkiä E. Effects of a three-month therapeutic exercise programme on flexibility in subjects with low back pain. Physiother Res Int. 2000;5(1):46-61.

9. Grewal H, Grewal BS, Patel R. Nonsurgical Interventions for low back pain. Prim Care. 2012;39(3):517-23

10. Fairbank J, Frost H, Wilson-MacDonald J, Yu LM, Barker K, Collins R. Randomised controlled trial to compare surgical stabilisation of the lumbar spine with an intensive rehabilitation programme for patients with chronic low back pain: the MRC spine stabilisation trial. BMJ. 2005:330(7502):1233.

11. Brox JI, Sørensen R, Friis A, Nygaard $\varnothing$, Indahl A, Keller, A, et al. Randomized clinical trial of lumbar instrumented fusion and cognitive intervention and exercises in patients with chronic low back pain and disc degeneration. Spine (Phila Pa 1976). 2003:28(17):1913-21.

12. Froholdt A, Reikeraas $\mathrm{O}$, Holm I, Keller A, Brox JI. No difference in 9-year outcome in CLBP patients randomized to lumbar fusion versus cognitive intervention and exercises. Eur Spine J. 2012;21(12):2531-8.
13. Fairbank JC, Pynsent PB. The Oswestry disability index. Spine (Phila Pa 1976). 2000;25 (22):2940-52.

14. Hayes MH, Patterson DG. Experimental development of the graphic rating method. Psychol Bull. 1921;18(1)98-9.

15. David JS. Handbook of parametric and nonparametric statistical procedures. 3rd ed. Boca Raton, FL: Chapman \& Hall/CRC: 2003. 423p.

16. Lee JH, Hoshino Y, Nakamura K, Kariya Y,Saita K, Ito K. Trunk muscle weakness as a risk factor for low back pain: a 5 year prospective study. Spine (Phila Pa 1976);1999; 24(1):54-7.

17. Feldman DE, Shrier I, Rossignol M, Abenhaim L. Risk Factors for the development of low back pain in adolescence. Am J Epidemiol. 2001;154(1):30-6.

18. Nourbakhsh MR, Arab AM. Relationship between mechanical factors and incidence of low back pain. J Orthop Sports Phys Ther. 2002;32(9):447-60.

19. Neves GAO. Avaliação da resistência muscular abdominal e mobilidade lombar em adultos portadores ou não de lombalgia crônica [monografia]. Curitiba: Pontifícia Universidade Católica do Paraná; 2010.

20. Poiraudeau S, Revel M. Rehabilitation therapy in chronic low back pain. Joint Bone Spine. 2000;67(6):582-7.

21. Vasselien $O$. Fladmark AM. Abdominal muscle contraction thickness and function after specific and general exercises: a randomized controlled trial in chronic low back pain patients. Man Ther. 2010;15(5):482-9.

22. Handa N, Yamamoto H, Tani T, Kawakami T, Takemasa, R. The effect of trunk muscle exercises in patients over 40 years of age with chronic low back pain. J Orthop Sci. 2000;5(3):210-6.

23. Shum GL, Tsung BY, Lee, RY. The immediate effect of posteroanterior mobilization on reducing back pain and the stiffness of the lumbar spine. Arch Phys Med Rehabil. 2013:94(4):673-9.

24. Fairbank JCT, Pynsent PB, Van Poortvliet JA, Phillips H. Influences of anthropometric factors and joint laxity in the incidence of adolescent back pain. Spine (Phila Pa 1976). 1984;9(5):461-4

25. Mierau D, Cassidy JD, Yong-Hing K. Low-back pain and straight leg raising in children and adolescents. Spine (Phila Pa 1976). 1989:14(5):526-8.

26. Jones MA, Stratton G, Reilly T, Unnithan VB. Biological risk indicators for recurrent non-specific low back pain in adolescents. Br J Sports Med. 2005;39(3):137-40. 